Menoufia J. Plant Prod., Vol. 6 April (2021): 221 - 233 https://mjppf.journals.ekb.eg/

\title{
PRIMITIVE EFFECTS OF CULTURE SYSTEM, SORBITOL AND SALICYLIC ACID ON GROWTH OF TISSUE CULTURE DERIVED DATE PALM PLANTS (PHOENIX DACTYLIFERA L.) AMRI CV. DURING ACCLIMATIZATION STAGE
}

\author{
M. R.M. Rabeh(1), E.G. Gadalla(2), S.A. Ahmed(1) and M.S. Shehata(2) \\ (1) Horticulture (Pomology) Department, Fac. of Agric., Menoufia Univ. \\ (2) The Central Laboratory for Date Palm Researches and Development, Agricultural \\ Research Center, Giza, Egypt.
}

Received: Apr. 10, 2021

Accepted: Apr. 24, 2021

\begin{abstract}
Date palm plantlets produced in vitro using tissue culture technique in a greenhouse face a great challenge that may lead to their death due to different ambient environmental conditions, moreover the slow growth rate of the survived tissue culture derived date palm plants during acclimatization are critical problems facing the tissue culture as a commercial technique of date palm propagation. Therefore, the success of date palm micropropagation is strongly linked to the success and quality of plantlets in the greenhouse. This study aimed to evaluate the effect of three different cultural systems on survival percentage, plant length, number of leaves and estimation photosynthetic pigments in greenhouse in the first experience as well as effect of foliar spray and watered three concentrations of Sorbitol $\left(0,15,30\right.$ and $\left.45 \mathrm{~g} \mathrm{l}^{-1}\right)$ and salicylic acid at concentrations $\left(0,20,40\right.$ and $\left.60 \mathrm{mg} \mathrm{l}^{-1}\right)$ on some vegetative growth parameters such as survival percentage, leaf width and growth vigor in the secondary experience. Findings indicated that using both the hydroponic (first culture system) and the traditional systems, with the addition of Barbary-Plante (third culture system) during the acclimatization stage gave highest values of survival percentage, plant length, number of leaves and chlorophyll $a+b$ content compared to the second culture system, where the lowest values were recorded. Also spraying and irrigation with sorbitol at $30 \mathrm{gl}^{-1}$ plus salicylic acid at $40 \mathrm{mg} \mathrm{l}^{-1}$ giving the highest values of survival percentage, leaf width and growth vigor $(91 \%, 2.73 \mathrm{~cm}, 4$, respectively) compared to other treatments.
\end{abstract}

Key word: Microprpagation - Date palm - Acclimatization stage - System culture Salicylic acid - Sorbitol.

\section{INTRODUCTION}

Date palm tissue culture technique was used for production of huge numbers of plants to farmers in order to meet the increasing demand for them. Date palm plantlets when transferred to ex vitro become stressful by different condition compared in vitro. in vitro condition saturated atmosphere, constant temperature $20-28 \mathrm{C}^{0}$, relatively low light intensity, high humidity, water continuously found, this in vitro condition lead to deficiency of plants morphology, physiology and anatomy as tiny shoots and leaves, small leaves and roots, low rates of photosynthesis, gas exchange, lowest contents of pigments, absent of cuticular wax (Darwesh, 2015). these plantlets must be acclimatize in the greenhouse for modified from heterotrophic to autotrophic status in order to increasing survive percent of plantlets for allowing enormous numbers of plants to farmers. plantlets usually need some period of acclimatization with gradual lowering in air humidity, adjust some differences for facing plants in a greenhouse such as light, relative 
humidity, nutrients and other growth promoters, the gaseous composition and the medium substrate (Seelye et al., 2003 and Chandra et al., 2010). Plantlets acclimatization can be considered as a major phase for successful establishment of micropropagated plantlets (Kumar and Rao, 2012), acclimatization stage was considered the most important stages in the commercial scale. To increasing acclimatization survival percent many treatments were used as pre-acclimatization in vitro, date palm cv., Different culture soil media and other factors anti-transpiration as well as reduce stress on plants.

Different culture soil media was used as, Tisserat (1984) elucidated that high survival rate was obtained when date palm plantlets were transplanted in pots containing a mixture of peat moss and vermiculite. Also the date palm cv Kheneizi plantlets were hardened and acclimatized and planted in pots, containing 1:1:1 peat, sand and dehydrated cow manure, which resulted in over $60 \%$ ex vitro plant survival (Kurup et al., 2014). Date palm cv. Maktoom (plantlets) were transplanted in peat moss and perlite $(2: 1)$ and placed in plastic tunnels in a greenhouse. With $85 \%$ a survival percentage (Khierallah and Bader, 2006). The substrate consisted of mixed coconut fiber and soft soil. The survival rate was over $90 \%$ after 3 weeks, by which time plants had welldeveloped leaves. Whilst, successful adaptation of vitro plantlets of date palm cv. Zaghlool when planted in pots contained equal volumes of peat moss and vermiculite under high humidity conditions (Bekheet, 2013). To increase relative humidity around the newly transferred plantlets of date palm, a micro-tunnel covered by transparent plastic was used. Every 2 to 3 days, plantlets were sprayed with a fungicide to prevent crown and leaf rot. Under such conditions, plantlets having 2 to 3 leaves, a well formed and closed crown and 3 to 4 roots showed a high survival rate (Abahmane, 2013).

Plantlets in a greenhouse are exposed to higher irradiance and lower humidity the plantlets may quickly wilt as water loss through transpiration is higher than that of absorption through roots. This condition is very severe in the dry regions where relative humidity is very low; irradiance and temperature are very high. Consequently, losses have been observed during the acclimatization process of in vitro derived plantlets in these regions. To overcome the above mentioned difficulties Al-Khalifah et al., (2010) suggested hydroponics techniques have been experimented for the acclimatization of three types of in vitro cultured plants: herb strawberry, shrub rose and tree date palm. Results indicated that the survival rate and growth vigor was significantly higher in the hydroponically grown plantlets compared to their conventionally grown controls. As, response to the two nutrient media used was also encouraging in the hydroponically grown plantlets. Transferring plantlets from the tube to a hydroponics system for a period of seven days has shown expedited establishment under ambient conditions in final soil media. Castañeda-Méndez et al., (2017) developed a simple hydroponic system to accelerate the cassava acclimation and multiplication process. This system considerably increased the survival percentage of in vitro.

Barbary-Plante (BP) is a soil conditioner consisting of a sodium acrylamide-acrilate copolymer with macro- and micronutrients and other components that improve nutrient availability, water retention, and aggregate stability in the soil. BP has been evaluated in several areas with good results. It was tested in Hyderabad, India, in corn and sunflower (Rao, 1997). 
In corn, it had a significant effect BP had a significant effect on Growth and productivity, also sunflower. BP has been tested in more than one country and may be useful to improve physical and chemical properties of media in addition to preserving moisture for as long as possible, while providing some nutrients and fungal prevention.

Salicylic acid enhancing cell division, biosynthesis of the natural hormones such as IAA, GA3 and cytokinins, nutrient and water uptake, photosynthesis, building of plant pigments and most organic nutrients (Singh et al., 2001). Moreover, It is an important phytohormone materially regulated growth of plants under stress conditions, ion uptake and transmission, photosynthesis, stomatal closure, membrane permeability, storage life, defense responses under biotic and abiotic stress conditions due to its action as plant significancy molecule. It activates the expression of several defense-related genes and induces synthesis of some enzymes that participate in proline biosynthesis or causes accumulation of proline and glycine-betaine which play a role as defense compounds under stress conditions. It extends plant cells age due to its action on inhibiting ethylene biosthyesis (Janda et al., 2007; Canakci and Manzuroglu, 2009 and Joseph et al., 2010). Application of salicylic acid, acetyl salicylic acid (aspirin), elemental sulphur, plantacur-E (a vitamin $E$ formulation containing $25 \%$ a-tocopherol) at $1 \%$, and oleic acid at $100 \mathrm{ppm}$, significantly increased plantlet survival percentages compared to the control (Awad et al., 2006).

Alcohol sugar or polyols is a carbohydrate that is one of the most important products of the process of photosynthesis. Sugar alcohols move freely and easily inside the plant. Sorbitol and mannitol, as alcohol sugars, are acting as osmotic regulators or as growth retardants by causing osmotic stress in plant culture media (EIDawayati et al., 2012). Osmotic stress has effects on morphological and physiological growing pattern of plant cultures (Ghaheri, et al., 2015). Shoot clusters explants which were cultured on rooting medium for 8 weeks with sorbitol sugar at $0.3 \mathrm{M}$ gave the best recovery of shoot elongation and good root system when were returned on normal rooting medium (Abd Elzaher et al., 2019). On the one hand nutrition, sugars alcohols works to penetrate the nutrients through the cuticle layer to the intercellular spaces between the cells in the leaves and the water stomata present on the whole leaf with a large concentration of water stomata around the guard cells and trichomes or capillaries and because the partial size of alcohol sugars is very small so it can pass and penetrate from inside the stomata in the cuticle layer (Nofal, 2018). May be Alcohol sugars are the best transporting system for a wide range of macro-nutrients and microelements and have an important role in the stages of plant growth.

The main objectives of this investigation are determining the best culture system, effect of different concentration salicylic acid, alcohol sugar (sorbitol) and their combination on growth and survival of date palm plantlets of Amri CV. for ex vitro acclimatization stage

\section{MATERIALS AND METHODS}

Two trials were conducted under the greenhouse conditions at the Central Laboratory for Date Palm Research and Development (CLDPRD), Giza, Egypt during 2018-2020. To improve vegetative growth and survival percentage of date palm plantlets of cv. Amri by using different culture systems, different 
M. R.M. Rabeh, et al.,

concentrations salicylic acid and alcohol sugar (sorbitol).

\section{First experiment:}

Plantlets $(13-14 \mathrm{~cm}$ in length, with distinct tap root system and 2-3 healthy leaves) derived from the previous stages were used and rinsed thoroughly with tap water then the root system was immersed in $0.25 \mathrm{~cm}^{3} \mathrm{I}^{-1}$ Pink S $30 \%$ (Hymexazol 30\% SL) fungicide solution for 2.5 minutes next $1 \mathrm{~g} \mathrm{l}^{-1}$ Moncut $25 \%$ WP (Flutolanil $25 \%$ wp) for 2.5 minutes as (Fig. 1). Afterwards, plantlets were planted individually in plastic pots (5x18 cm) filled with indifferent mixtures of culture media as follows:

Frist culture system: Hydroponic system, the system consisted of a small plastic container $(30 \mathrm{~cm}$ width $\times 50 \mathrm{~cm}$ length $\times 20 \mathrm{~cm}$ depth). The plastic pots were filled with a mixture of sand and foam beads of small diameter, washed well, then cultured the plantlets in them, covered them with this mixture and put them in the container. The nutrient solution was pumped from a small feeding tank to a small plastic container by tube of polyethylene (Fig. 2).

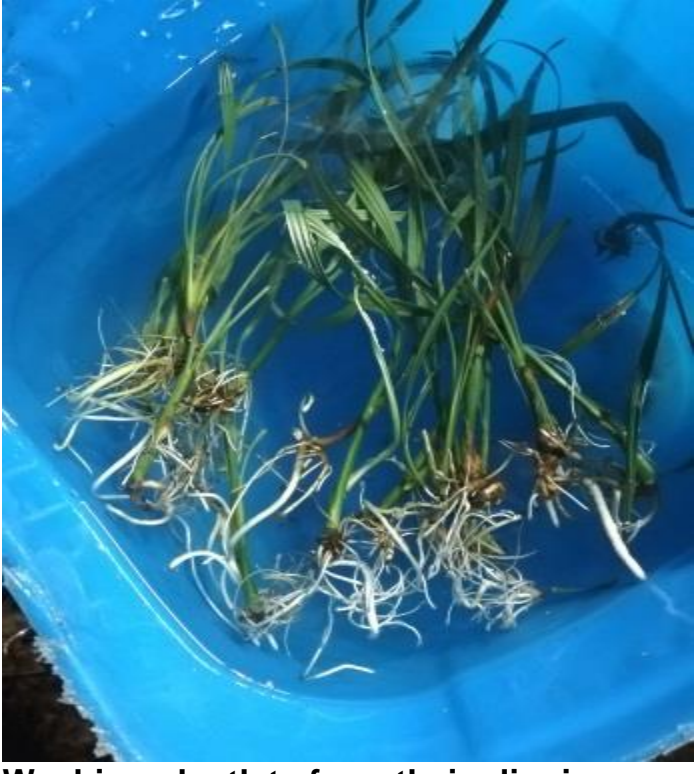

Washing plantlets from their clinging medium before acclimatization them.

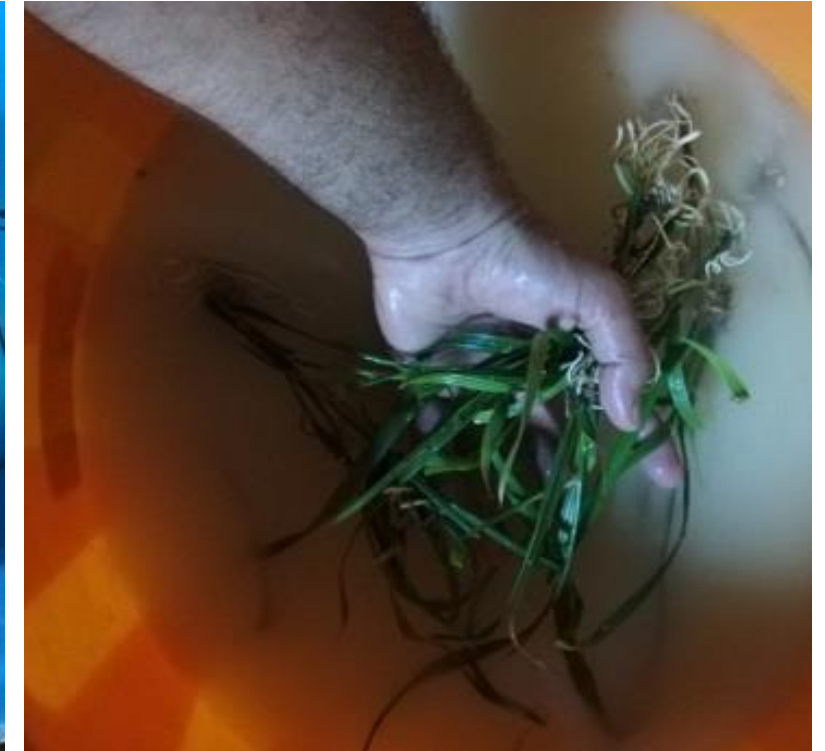

the root system was immersed in fungicide solution

Fig (1): Preparing plants for acclimatization in a greenhouse.

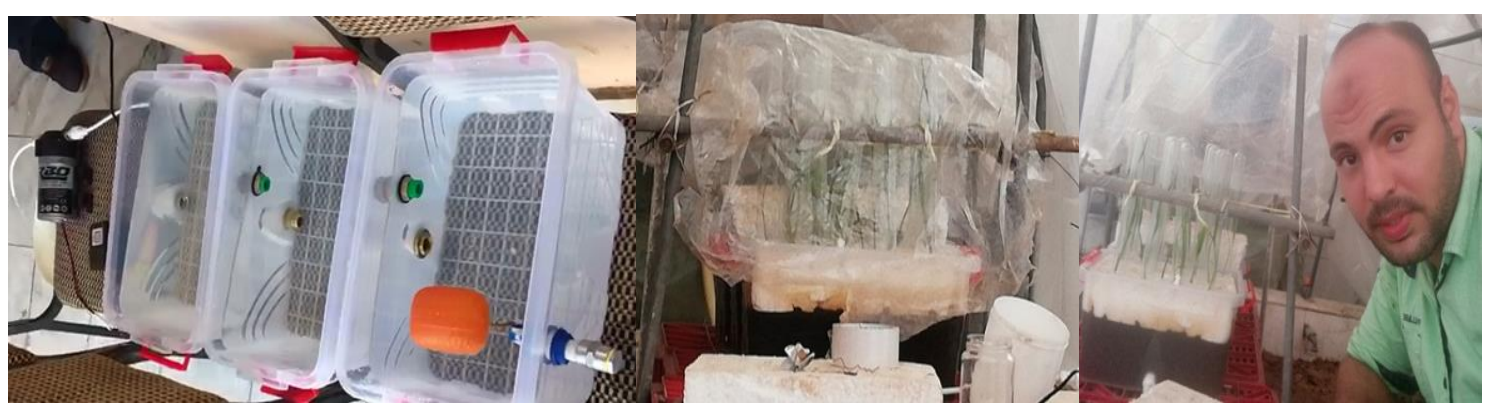

Fig: (2) prepration first culure system (Hydroponic) 
Second culture system: Traditional culture media According to Shehata (2014). Plantlets were cultured in plastic pots filled with mixture peat moss and perlite $(1: 1, v / v)$. The plantlets were watered intervals, twice a week.

Third culture system: Traditional culture media plus Barbary-Plante (soil conditioner): Barbary-Plante (BP), the compound is a sodium acrylamideacrilate copolymer containing macro- and microelements, fungicide and root growth promoter in Table (1).

$B P$ is manufactured by the French company Barbary-Plante International and distributed in Egypt by Tanta Company. Plantlets were cultured in plastic pots filled with mixture peat moss and perlite $(1: 1, \mathrm{v} / \mathrm{v})$ plus $3 \mathrm{~g} /$ pot BarbaryPlante. The plantlets were watered once a week with the solution.

All plantlets in this experiment was watered with a solution consisting of half strength MS and $1 \mathrm{~g} \mathrm{l}^{-1}$ Fulvic acid, all culture vessels were covered with a transparent plastic lid, making a microenvironment with a high relative humidity (more than $80 \%$ ), through which light can pass while protecting the plantlets against a possible mechanical damage. The humidity was gradually reduced to adaption the plantlets to greenhouse conditions by making holes in the plastic lid every 2 weeks to be completely removed eight weeks later of cultivation.

All plantlets in this trial were incubated under lighting conditions by using fluorescent lamps illuminations of 10000-15000 Lux for photoperiod of 16 hrs/day at $27 \pm 1^{\circ} \mathrm{C}$ under plastic tunnel inside greenhouse. The following data were recorded after 12 weeks: Survival percentage, plant length, number of leaves and estimation photosynthetic pigments.

\section{Estimation of Photosynthetic pigments:}

The amount of chlorophyll was estimated by the method described by (Wettstein, 1957) using a spectrophotometer at $662 \mathrm{~nm}$ for chlorophyll a, $640 \mathrm{~nm}$ for chlorophyll b, then the total chlorophyll was calculated and $440 \mathrm{~nm}$ for carotenoids.

This experiment was conducted on plants growing in a mixture peat moss and perlite $(1: 1, \mathrm{v} / \mathrm{v})$ plus $3 \mathrm{~g} /$ pot BarbaryPlante (third culture system) to investigate the effect of foliar spray and watered three concentrations of Sorbitol $\left(0,15,30\right.$ and $\left.45 \mathrm{~g} \mathrm{l}^{-1}\right)$ and salicylic acid at concentrations $\left(0,20,40\right.$ and $\left.60 \mathrm{mg} \mathrm{l}^{-1}\right)$ on some vegetative growth parameters.

Table 1: Barbary-Plante composition reported by manufacturer.

\begin{tabular}{cccc}
\hline \multicolumn{3}{c}{ Component } & \\
\hline Macroelements & $\%$ & Microelements & $\mathrm{mg} / \mathrm{kg}$ \\
\hline & & $\mathrm{Cu}$ & 200 \\
$\mathrm{~N}-\mathrm{P}-\mathrm{K}$ & $\mathrm{Fe}$ & 60 \\
& $18-18-18$ & $\mathrm{Zn}$ & 480 \\
& & $\mathrm{Mn}$ & 160 \\
Fungicides & & Mo & 600 \\
Hymexazol & $\%$ & Plant Growth Regulators & 60 \\
Potassium Hydroxide & 20 & 1-Naphthaleneacetamide & 0.018 \\
& 45 & 1-Naphthaleneacetic acid & 0.002 \\
& & Thio-urea & 0.098 \\
\hline
\end{tabular}




\section{Secondary experiment:}

The plantlets were watered once or Twice as needed a week with the aforementioned solution added to $\mathbf{0 . 5}$ g I $^{-1}$ NUTRI-LEAF $^{\circledR}$, It is 20:20:20 NPK with the rest macro and micro elements manufactured by Miller Chemical and Fertilizer Corporation was founded in Baltimore, Maryland, U.S.A. and it was bought from Wadi El Nil for Agricultural Development Company in Egypt.

Each plantlet was received treatment twice. The first was performed 12 weeks after planting and the second 15 days after the first and repeat four times then data were recorded after 12 weeks (Growth vigor, Leaf width and Survival percentage). Plantlets from different treatments were grown under the same previous conditions of temperature, humidity and lighting.

\section{Statistical analysis}

Experiments were carried out in a completely randomized design. Data were analyzed by using the Statistical Package for the Social Science (SPSS) v.16.0 software. The significant of differences between treatments were evaluated using the analysis of variance (ANOVA) followed by Tukey's range post-hoc test at 0.05 level of significance.

\section{RESULTS AND DISCUSSION}

Improving plantlet growth by using three different cultural systems during acclimatization stage.

Data presented in Table and Fig. (2, 3, respectively) indicate that survival percentage, plant length, number of leaves and estimation photosynthetic pigments in greenhouse after 12 weeks was influenced by three different cultural systems used in the experiment, to choose the best culture system to use during the acclimatization stage. the highest survival percentage (83.33\%) was in the first culture system, while this percentage was reduced to $(71 \%)$ in the secondary culture system. On other hand, it was found that the maximum plant height $(21 \mathrm{~cm})$ in third culture system while the minimum plant height $(16.83 \mathrm{~cm})$ in secondary culture system. As well as, the number of leaves was 4 in the third culture system while was reduced to $\mathbf{2 . 3 3}$ in the secondary culture system. In addition, the results showed that the highest chlorophylls content in the plant was found in the third culture system, while the lowest chlorophylls content was found in the first culture system as the chlorophylls content were 46.12 and 42.24 respectively. Also, the results indicated that the highest carotenoids content was $\mathbf{9 . 4 6}$ in the first culture system, which the lowest content was 8.21 in the third culture system.

The results obtained indicate that acclimatization of the plants in the greenhouse using the hydroponic system gave the best results and this may be due to the high humidity and nutrients for plants. Put with the observation of fungal infections may be due to increased humidity.

Once the plants into the greenhouse, they exposed to higher irradiance and lower humidity the plantlets may quickly wilt as water loss through transpiration is higher than that of absorption through roots, the resulting higher loss percentage in plants which leads to Heavy losses during the acclimatization process of in vitro derived plantlets especially in dry regions. 
Table 2: Survival percentage and vegetative growth parameters assessment of Amri cultivar date palm cultured on three different cultural systems during acclimatization stage for 12 weeks.

\begin{tabular}{cccccc}
\hline $\begin{array}{c}\text { Cultures system/ } \\
\text { Observation }\end{array}$ & $\begin{array}{c}\text { Survival } \\
\text { percentage }\end{array}$ & $\begin{array}{c}\text { Plant } \\
\text { length }\end{array}$ & $\begin{array}{c}\text { Number of } \\
\text { leaves }\end{array}$ & $\begin{array}{c}\text { Chlorophylls } \\
\mathbf{a}+\mathrm{b}\end{array}$ & Carotenoids \\
\hline $\begin{array}{c}\text { Frist culture } \\
\text { system }\end{array}$ & 83.33 & 19.50 & 3.33 & 42.24 & 9.46 \\
$\begin{array}{c}\text { Secondary } \\
\text { culture system } \\
\begin{array}{c}\text { Third culture } \\
\text { system }\end{array}\end{array}$ & 71.00 & 16.83 & 2.33 & 44.34 & 8.57 \\
\hline LSD at $5 \%$ & 80.33 & 21.00 & 4.00 & 46.12 & 8.21 \\
\hline
\end{tabular}

In a proposal to overcome these difficulties, we proposed 3 culture systems, the results for the hydropionic system were high in survival percent and this is consistent with the results obtained Al-Khalifah et al., (2010) suggested hydroponics techniques have been experimented for the acclimatization of three types of in vitro cultured plants: herb strawberry, shrub rose and tree date palm. Results indicated that the survival rate and growth vigor was significantly higher in the hydroponically grown plantlets compared to their conventionally grown controls. As, response to the two nutrient media used was also encouraging in the hydroponically grown plantlets. Transferring plantlets from the tube to a hydroponics system for a period of seven days has shown expedited establishment under ambient conditions in final soil media. Also Castañeda-Méndez et al., (2017) developed a simple hydroponic system to accelerate the cassava acclimation and multiplication process. This system considerably increased the survival percentage. Using BarbaryPlante with traditional media (Third culture system) led to an increase in
Plant length, Number of leaves, Chlorophylls $a+b$ content, noting that $a$ very low percentage of fungal infections may be due to the components of BP and the low humidity Compared to hydroponics.

Previous increases may be due to the BP content of macroelements, microelements, fungicides, plant growth regulators, hymexazol, naphthaleneacetamide, potassium hydroxide, naphthaleneacetic acid, which in turn improves growth and provides suitable humidity for plants, moreover improve nutrient availability, water retention, and aggregate stability in the soil. These results are similar to the results of the following research. BP has been evaluated in several areas with good results. It was tested in Hyderabad, India, in corn and sunflower (Rao, 1997). in corn, it had a significant effect BP had a significant effect on the growth and productivity of plants, may be useful to improve physical and chemical properties of culture media in addition to preserving moisture for as long as possible, while providing some nutrients and fungal prevention. 


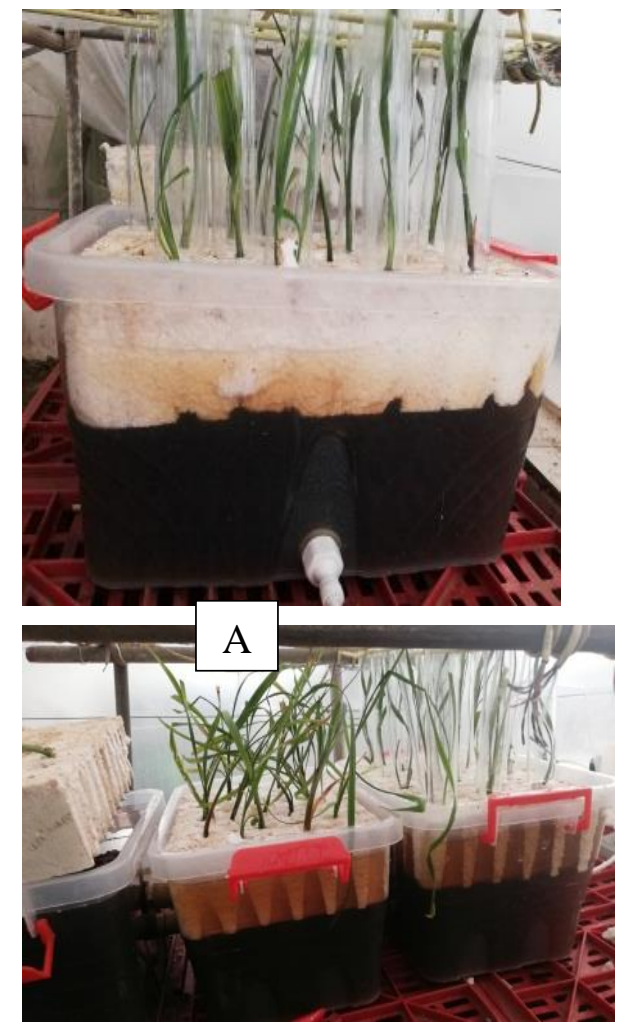

A. Effect of First culure system (Hydroponic) on survival and growth plants

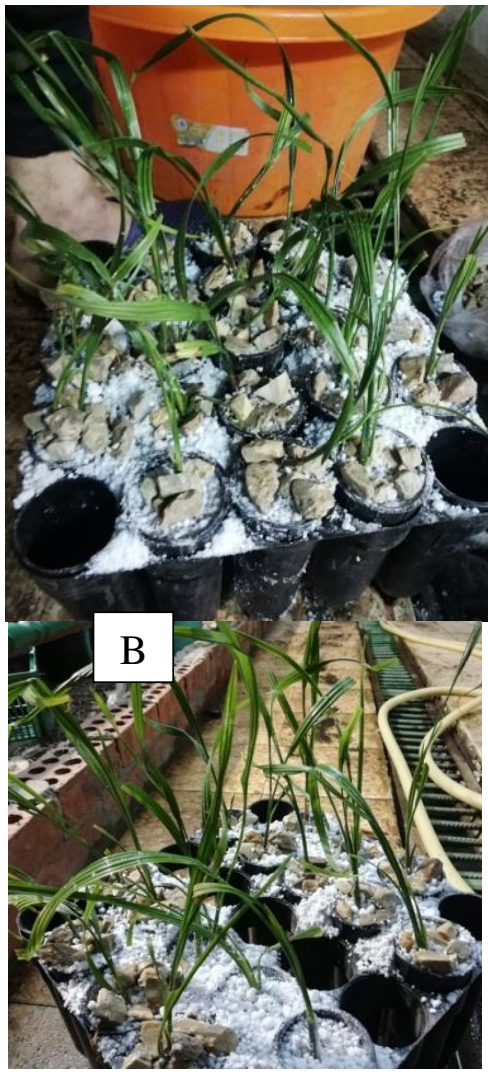

B.Effect of third culure system (tradional $+\mathrm{Bp}$ ) on survival and growth plants.

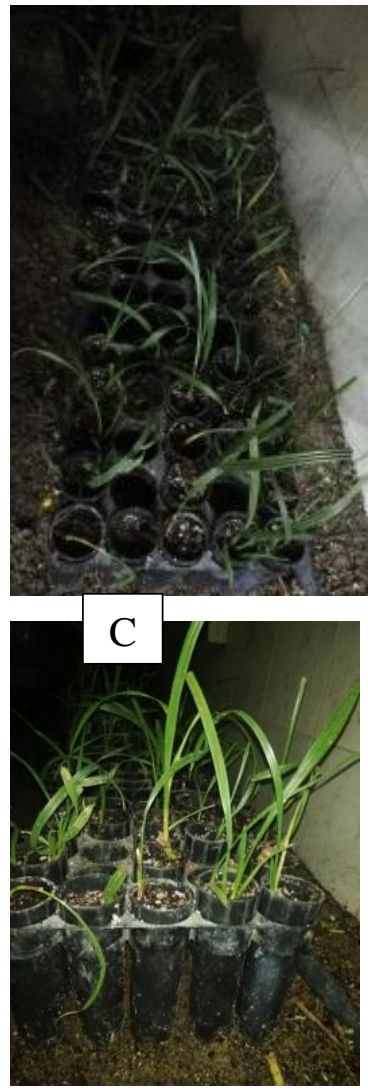

C. Effect of

Secondary culure system (traditional) on survival and growth plants

Fig (3): Survival percentage and vegetative growth parameters assessment of Amri cultivar date palm cultured on three different cultural systems during acclimatization stage.

Effect of alcohol sugars (sorbitol) and salicylic acid on plantlets growth in greenhouse.

This experiment was conducted on plants growing in a mixture peat moss and perlite $(1: 1, \mathrm{v} / \mathrm{v})$ plus $3 \mathrm{~g} /$ pot BarbaryPlante to investigate the effect of foliar spray and watered three concentrations of Sorbitol $\left(0,15,30\right.$ and $\left.45 \mathrm{~g} \mathrm{l}^{-1}\right)$ and salicylic acid at concentrations $(0,20,40$ and $60 \mathrm{mg} \mathrm{l}^{-1}$ ) on some vegetative growth parameters such as survival percentage, leaf width and growth vigor.

Data in Table (3, 4 and 5) and Fig (4) showed that significant differences among treatments could be noticed where sorbitol concentration at $30 \mathrm{~g} \mathrm{l}^{-1}$ recorded the highest survival value, leaf width and growth vigor $(83.42 \%, 1.92 \mathrm{~cm}$ and 3.33 respectively). Concerning to salicylic acid concentrations at $40 \mathrm{mg} \mathrm{l}^{-1}$, it gave higher significant values (survival $81.92 \%$, leaf width $2.16 \mathrm{~cm}$ and growth vigor 3.33 respectively. The interaction between two studied factors showed significant differences among treatments where sorbitol at $30 \mathrm{~g} \mathrm{l}^{-1}$ whit salicylic acid at $40 \mathrm{mg} \mathrm{l}^{-1}$ recorded the highest survival value, leaf width and growth vigor (91\%, $2.73 \mathrm{~cm}$ and 4 respectively), while treatment control gave lowest values. 
Table 3: Influence of alcohol sugar (sorbitol) and salicylic acid on Survival percentage of plantlets Amri cultivar date palm in greenhouse for 12 weeks.

\begin{tabular}{cccccc}
\hline \multirow{5}{*}{$\begin{array}{c}\text { salicylic acid } \\
\left(\mathrm{mg} \mathrm{l}^{-1}\right)\end{array}$} & \multicolumn{5}{c}{ Survival percentage } \\
\cline { 2 - 6 } & 0 & 15 & 30 & 45 & Mean (A) \\
0 & 73.67 & 75.00 & 77.67 & 78.00 & 76.08 \\
20 & 73.00 & 75.33 & 78.67 & 74.33 & 75.33 \\
40 & 72.67 & 79.00 & 91.00 & 85.00 & 81.92 \\
60 & 74.67 & 79.00 & 86.33 & 86.33 & 81.58 \\
Mean (B) & 73.50 & 77.08 & 83.42 & 80.92 & \\
\hline LSD at 5\% & A 0.66 & B 0.66 & AxB 1.31 & \\
\hline
\end{tabular}

Table 4: Influence of alcohol sugar (sorbitol) and salicylic acid on Leaf width of plantlets Amri cultivar date palm in greenhouse for 12 weeks.

\begin{tabular}{cccccc}
\hline \multirow{2}{*}{$\begin{array}{c}\text { salicylic acid } \\
\left(\mathrm{mg} \mathrm{l}^{-1}\right)\end{array}$} & \multicolumn{5}{c}{ Leaf width } \\
\cline { 2 - 6 } & 0 & 15 & 30 & 45 & Mean (A) \\
0 & 0.60 & 0.90 & 1.10 & 1.30 & 0.98 \\
20 & 0.97 & 1.33 & 1.97 & 1.80 & 1.52 \\
40 & 1.90 & 1.87 & 2.73 & 2.13 & 2.16 \\
60 & 1.97 & 2.10 & 1.87 & 1.90 & 1.96 \\
Mean (B) & 1.36 & 1.55 & 1.92 & 1.78 & \\
\hline LSD at 5\% & A 0.08 & B 0.08 & AxB 0.16 & \\
\hline
\end{tabular}

Table 5: Influence of alcohol sugar (sorbitol) and salicylic acid on Growth vigor of plantlets Amri cultivar date palm in greenhouse for 12 weeks.

\begin{tabular}{cccccc}
\hline \multirow{2}{*}{$\begin{array}{c}\text { salicylic acid } \\
\left(\mathrm{mg} \mathrm{l}^{-1}\right)\end{array}$} & \multicolumn{5}{c}{ Growth vigor } \\
\cline { 2 - 6 } & 0 & 15 & 30 & 45 & Mean (A) \\
0 & 2.00 & 2.33 & 2.33 & 2.67 & 2.33 \\
20 & 2.33 & 2.33 & 3.33 & 2.67 & 2.67 \\
40 & 3.00 & 3.33 & 4.00 & 3.00 & 3.33 \\
60 & 2.00 & 2.67 & 3.67 & 2.67 & 2.75 \\
Mean (B) & 2.33 & 2.67 & 3.33 & 2.75 & \\
\hline LSD at 5\% & A 0.44 & B 0.44 & AxB 0.8 & \\
\hline
\end{tabular}




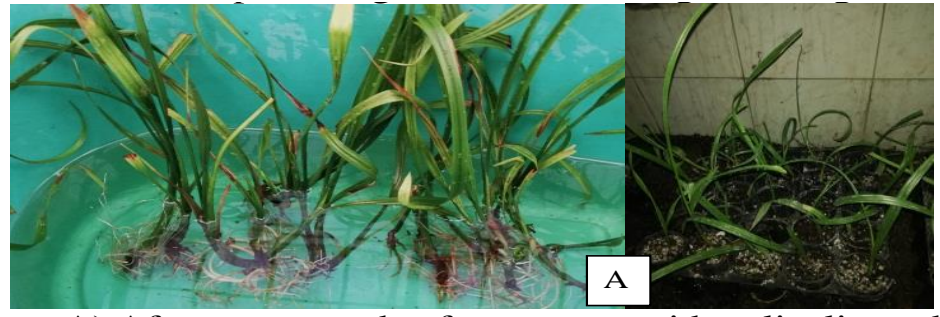

A) After one month of treatment with salicylic and sorbitol

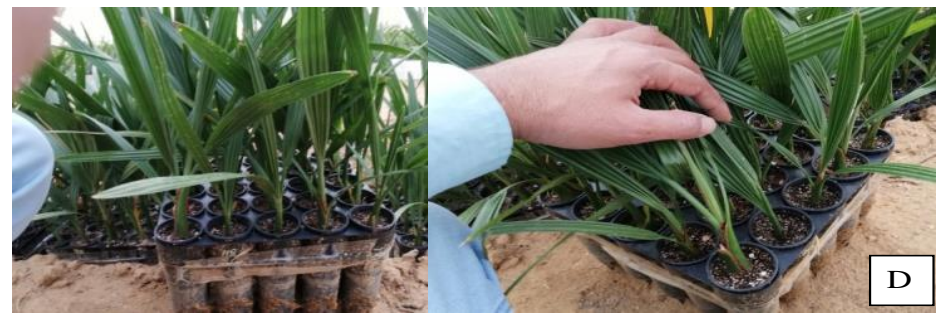

D) Successful acclimatization of plants after 12 months

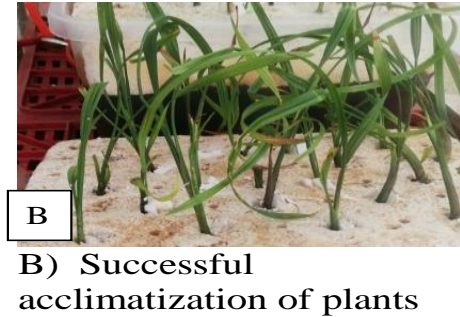

after 3 months

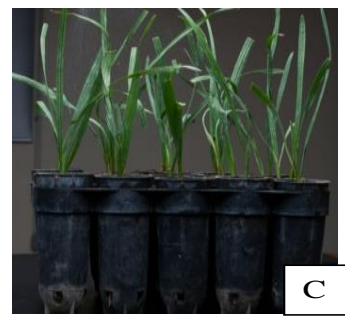

C) Successful

acclimatization of plants after 6 months

Fig. (4): Influence of combination between salicylic acid at $40 \mathrm{mg} \mathrm{l}^{-1}+$ sorbitol at $30 \mathrm{~g} \mathrm{l}^{-1}$ on survival percentage, leaf width and growth vigorof plantlets.

The results of this experiment are summarized in: Treatment plantlets with spraying and irrigation with sorbitol at $\mathbf{3 0}$ $\mathrm{gl}^{-1}$ plus salicylic acid at $40 \mathrm{mg} \mathrm{l}^{-1}$ giving the highest values of survival percentage, leaf width and growth vigor (91\%, $2.73 \mathrm{~cm}, 4$ respectively) compared to other treatments, this may be due to the effects of both salicylic and sorbitol, salicylic acid is an important phytohormone materially regulated growth of plants under stress conditions, ion uptake and transmission, photosynthesis, stomatal closure, membrane permeability, storage life, defense responses under biotic and abiotic stress conditions due to its action as plant significance molecule. in addition to It extends plant cells age due to its action on inhibiting ethylene biosthyesis (Canakci and Manzuroglu, 2009 and Joseph et al., 2010).

These results are in agreement with those obtained by some investigators
Awad et al., (2006) Studied the effect of foliar and soil application of antistress substances and elemental sulphur, respectively, on growth and survival percentage of tissue culture-derived 'Khalas' date palm plantlets during acclimatization were studied. The results showed that application of salicylic acid, acetyl salicylic acid (aspirin), elemental sulphur, plantacur-E at $1 \%$, and oleic acid at $100 \mathrm{ppm}$, significantly increased plantlet survival percentages compared to the control. moreover, salicylic acid enhancing cell division, biosynthesis of the natural hormones such as IAA, GA3 and cytokinins, nutrient and water uptake, photosynthesis, building of plant pigments and most organic nutrients (Singh et al., 2001).

Alcohol sugar is a carbohydrate that is one of the most important products of the process of photosynthesis. Sugar alcohols move freely and easily inside the plant. The application of sorbitol on 
Strawberry at $25 \mathrm{~g} \mathrm{l}^{-1}$ spraying caused a significant increase in leave number, leaf area, plant leave area and the vegetative dry weight, compared with treatment control (Moulin and Obaid, 2019).

Alcohol sugars are the best transporting system for a wide range of macro-nutrients and microelements and have an important role in the stages of plant growth.

\section{REFERENCES}

Abahmane, L (2013). Recent achievements in date palm (Phoenix dactylifera L.) micropropagation from inflorescence tissues. Emirates Journal of Food and Agriculture, 863-874.

Abd Elzaher, M. H., S. M. Abd Elwahab, S. F. Elsharabasy, M. M. El-Dawayati and H. A. Fouad (2019). Rooting recovery and chemical analysis of date palm shootlets after sorbitol and mannitol sugars stress. Plant Archives Vol. 19: 886-894.

Al-Khalifah, N. S., A. E. Shanavaskhan and F. Ahmed Khan (2010). Utilizing hydroponics technique for acclimatizing tissue culture derived plantlets under desert environment. Acta Hortic. 865, 163-170.

Awad, M. A., A. A. Soaud and S. M. ElKonaissi (2006). Effect of exogenous application of anti-stress substances and elemental sulphur on growth and stress tolerance of tissue culture derived plantlets of date palm (Phoenix dactylifera L.) cv. 'Khalas' during acclimatization. Journal of Applied Horticulture, 8(2): 129-134.

Bekheet, S. (2013). Direct organogenesis of date palm (Phoenix dactylifera L.) for propagation of true-to-type plants. Science Agriculture, 4: 85-92.

Canakci, S. and O. Manzuroglu (2009). Effect of salicylic acid on growth and chlorophyll destruction of some plant tissues. World Journal of Agric. Sci. 5(5): 577-581.

Castañeda-Méndez, O., S. Ogawa, A. Medina, P. Chavarriaga and M. G. Selvaraj (2017). A simple hydroponic hardening system and the effectof nitrogen source on the acclimation of in vitro cassava (Manihotesculenta Crantz). In vitro Cell.Dev. Biol. Plant 53:75-85.

Chandra, S., R. Bandopadhyay, V. Kumar and R. Chandra (2010). Acclimatization of tissue cultured plants: from laboratory to land. Biotechnol. Lett. 32: 1199-1205.

Darwesh, R. S. S (2015). Morphology, physiology and anatomy in vitro affected acclimatization ex vitro date palm plantlets: A Review. International Journal of Chemical, Environmental \& Biological Sciences (IJCEBS) 3, 2: 175-182.

El Dawayati, M. M., O. H. Abd El Bar, Z. E. Zaid and A. F. Zin EI Din (2012). In vitro morpho-histological studies of newly developed embryos from abnormal malformed embryos of date palm cv. Gundila under desiccation effect of polyethelyne glycol treatments. Ann. Agric. Sci., 57: 117-128.

Ghaheri, M; D. Kahrizi; and G. Bahrami (2015). Effect of mannitol on some morphological characteristics of In vitro Stevia rebaudiana Bertoni. Biharian. Biol, 11(2): 94-97.

Janda T; G. Horvath; G. Szalai and E. Paldi (2007) Role of salicylic acid in the induction of abiotic stress tolerance. In Hayat S, Ahmad A, eds Salicylic Acid, A plant Hormone. Springer Publishers, Dordrecht, The Netherlands.

Joseph, B., D. Jini and S. Sujatha (2010). Insight into the role of exogenous salicylic acid on plants grown under 
M. R.M. Rabeh, et al.,

salt environment. Asian J. Crop Sci, 2: 226-235.

Khierallah, H. S and S. M. Bader (2006). Micropropagation of date palm (Phoenix dactylifera L.) var. Maktoom through direct organogenesis. In "III International Date Palm Conference, 736: pp. 213224.

Kumar, K. and I.U. Rao (2012). Morphophysiologicals problems in acclimatization of micropropagated plants in ex vitro conditions- A review. J. Ornam. Hort. Plants 2: 271-283.

Kurup, S. S; M. A. M. Aly; G. Lekshmi and N. H. Tawfik (2014). Rapid in vitro regeneration of date palm (Phoenix dactylifera L.) cv. Kheneizi using tender leaf explant. Emir. J. Food Agric., 26 (6): 539-544.

Moulin, H. R. and I. A. Obaid (2019). effect of sorbitol and boron spraying on vegetative growth andflowering of strawberry fragaria ananassa duch. cv. ruby gem. Arab Journal of Sciences and Research Publishing, 2(3): 2522-3364.

Nofal, M. (2018). Sugar Alcohol Fertilizer Technology. https://www.agri2day.com.

Rao, M. (1997). Evaluation of BarbaryPlante on water stress management in maize and sunflower. Progress Report Nagarjuna Agrl. Research and Development Institute. Hyberabad, India.

Seelye, J. F., G. K. Burge and R. Morgan (2003). Acclimatizing tissue culture plants: reducing the shock. Combined Proceed. Int. Plant Prop. Soc. 53: 85-90.

Shehata, M. S (2014). Studies of date palm micropropagation. M.Sc. Thesis, Department of Horticulture (pomology), Faculty of Agriculture, Menoufia University, Egypt.

Singh, D. V., G. C. Srivastava and M. S. Abdin (2001). Amelioration of negative effect of water stress in Gassiaangustifolia by benzyladenine and/ or ascorbic acid. Bidoyiaplantarum, 44 (1): 141-143.

Tisserat, B. (1984). Propagation of date palm by shoot tip cultures. Hort. Sci. 19: 230-231.

Wettstein, D. (1957). Formula of chlorophyll determination. Exp. Cell Res. 12(3): 427-489. 
التأثيرات المحفزة لنظام الزراعة والسكر الكحولي وحمض الساليسيليك على نمو نباتات نخيل

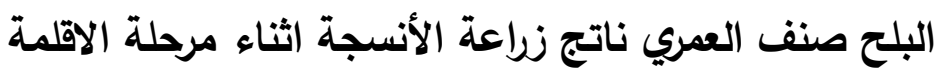

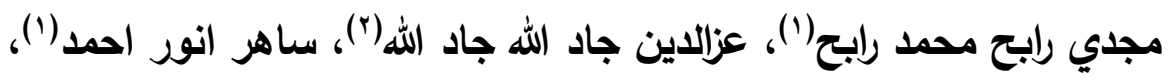

\section{محمود صديق شحاته(r)}

(1) قسم البساتين (فاكهة) - كلية الزراعة جامعة المنوفية - شبين الكوم.

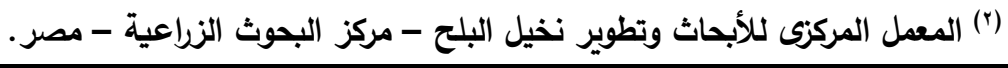

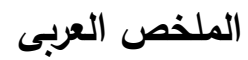

تواجه نبيتات النخيل المنتجة معمليا بإستخدام تكنيك زراعة الانسجة في الصوبة تحديا كبيرا قد يؤدي الي موتها بسبب

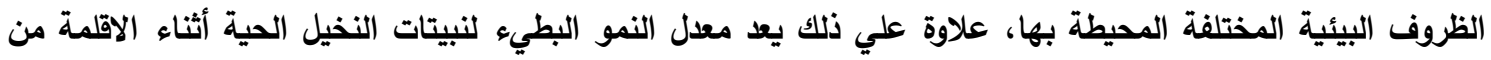

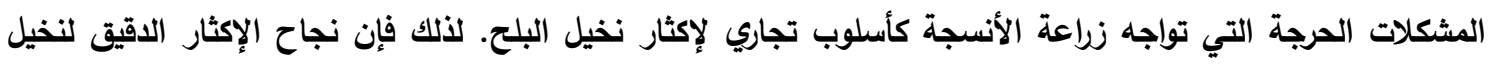

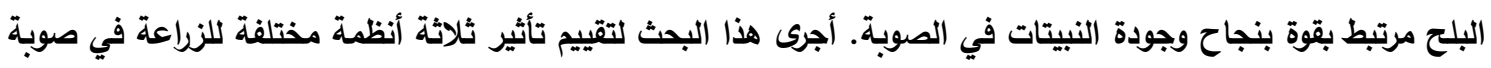

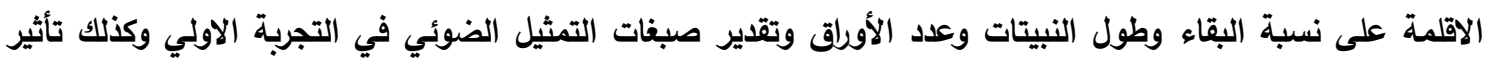

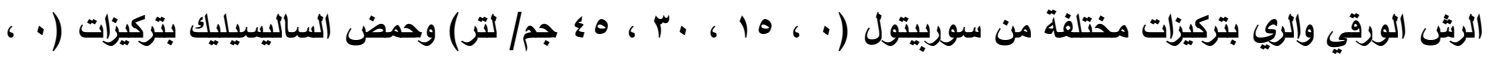

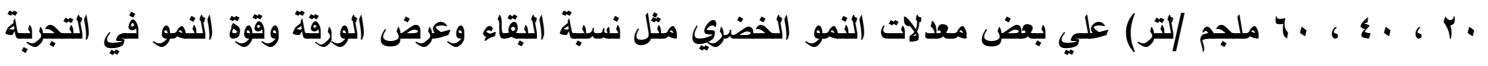

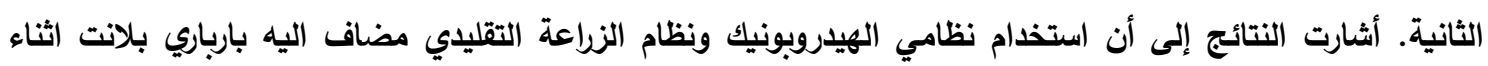

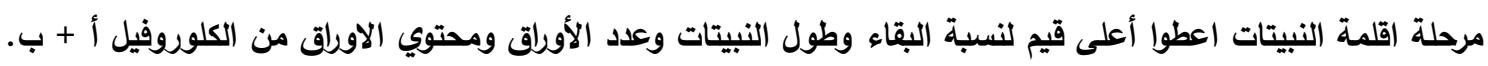

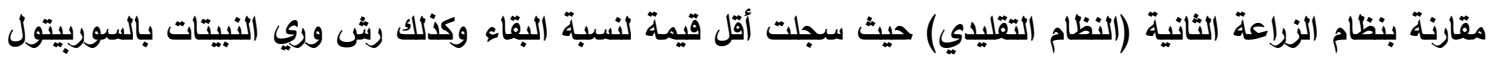

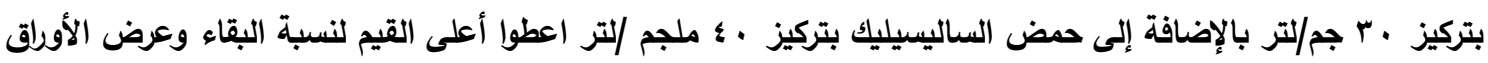

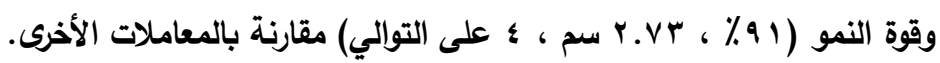

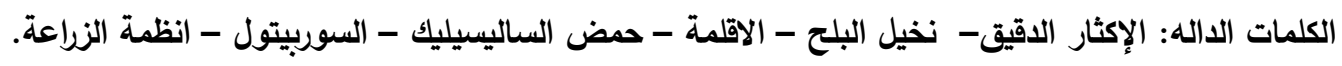

أسماء السادة المحكمين

أ.د/ طلعت على أبو سيد أحمد كلية الزراعة - جامعة الزقازيق أ.د/ محمد سامى مليجى عبدالعزيز معهـ بحوث البساتين - مركز البحوث الزراعية - الجيزة 